\title{
Monitoring of Metal Dispersion in Kumaon Hills (INDIA) Through Active Monitoring Using Moss
}

\author{
Dinesh K. Saxena $^{a *}$, Isam Janajreh ${ }^{b}$ and Dheeraj Gahtori ${ }^{a}$ \\ ${ }^{a}$ Bryology laboratory, Botany Department, Bareilly College, Bareilly-243005 (U.P), INDIA \\ ${ }^{b}$ Mechanical and Materials Engineering Program, Masdar Institute, Abu Dhabi, PO Box 54224, UAE
}

\begin{abstract}
Bryophytes have been used as a terrestrial bio-monitors and bio-indicators of air pollution and are recognized as more sensitive to pollution than other plants. In present study common moss species, i.e. Rhodobryumgiganteum (Schwaegr) Par., Rhynchostegielladivaricatifolia (Renauld\&Cardot), PohliaelongataHedw, Racomitriumcrispulum (Hook. f. et Wils.), Pleuroziumshcreberi, Hylocomiumsplendens, Hypnumcupressiforme, Brachytheciumrutabulum, Homalotheciumsericeum, Racomitriumcrispulum were collected from monitoring sites and were validated for their tolerance potential by measuring chlorophyll fluorescence signals. Amongst above species validated for tolerance, moss Racomitriumcrispulum (Hook. f. et Wils.) is inducted for monitoring program. Collected samples were air dried, then cleaned and digested. The levels of $\mathrm{Zn}, \mathrm{Cu}, \mathrm{Cd}$ and $\mathrm{Pb}$ have been determined in transplants of the moss Racomitriumcrispulum (Hook. f. et Wils.) from the area of Almora, Nainital and Pithoragarh of Kumaon hills. High metallic load was measured in moss harvested from locations in proximity of higher traffic density areas, which is attributed to the enhanced tourism during summer and monsoon season. In rural areas high value of $\mathrm{Zn}$ and, $\mathrm{Cu}$ attributes to their use in fertilizers. Positive significant correlations were obtained between $\mathrm{Pb}-\mathrm{Zn}$ and $\mathrm{Zn}-\mathrm{Cu}$ that suggest a common origin of these metals. Elemental concentration in moss Racomitriumcrispulum was in order $\mathrm{Zn}>\mathrm{Pb} \sim \mathrm{Cu}>\mathrm{Cd}$ in summer while, same was $\mathrm{Zn}>\mathrm{Cu}>\mathrm{Pb}>\mathrm{Cd}$ in winter season and in rain $\mathrm{Zn}>\mathrm{Cu}>\mathrm{Pb}>\mathrm{Cd}$ that reflects atmospheric trace elemental load. Bioaccumulation ability of this moss was evaluated statistically using DMR test and cartographically presented on contour maps obtained from SURFER program.
\end{abstract}

Key words: Metal Emission, Kumaon hills, moss Racomitriumcrispulum (Hook. f. etWils.), active monitoring.

\section{Introduction}

Even in the advanced civilizations of the ancient world, the use of metals reached an order of magnitude that can be detected as metal deposition on global scale [1] [2]. Environmental pollution is a problem, both in developed and developing countries [3]. Factors such as population growth and urbanization invariably place greater demand on the planet and stretch the use of natural resources to the maximum.

Rapid industrialization and urbanization in the last century has greatly increased both quantity and quality of metal production worldwide. Air pollution comes from many different sources: stationary sources such as factories, power plants, smelters and smaller sources such as dry cleaners and degreasing operations; mobile sources such as cars, buses, planes, trucks and trains; and naturally occurring sources such as windblown dust and volcanic eruptions. Air pollution has many disastrous effects that need to be curbed. In order to accomplish this, governments, scientists and environmentalists are using or testing a variety of methods aimed at reducing pollution.
Anthropogenic source of metals can have a serious impact on environment; therefore, continuous or regular assessment of parameters depicting the state of the environment is pre-requisite for abatement of their sources in their respective region $[4,5]$. The metals $\mathrm{As}, \mathrm{Cr}, \mathrm{Be}, \mathrm{Cu}, \mathrm{Cd}, \mathrm{Zn}, \mathrm{Hg}$ and $\mathrm{Pb}$ are closely associated with air precipitation and are derived from a wide spectrum of natural and anthropogenic sources [6]. In recent decades the number and intensity of anthropogenic sources have increased the overall environmental element concentration [7, 8]. This fact seems to be true for the Kumaon hills (India). High concentration of metals is a major source of environmental pollution in the ecosystem may lead to an excessive accumulation, which may be toxic to plants and cause possible health problem to animals and human. Determining environmental concentrations is an important part of understanding biogeochemical processes and gauging ecosystem's health.

Use of mosses as bio-monitor is a suitable method for determining the total levels of atmospheric deposition of metals and its trend due to their accumulation capability $[9,10]$. The method is generally simple and relatively inexpensive when compared to direct measurement techniques without

\footnotetext{
${ }^{*}$ Corresponding author. Tel.: +91-581-2567170, + +97128109130

E-mail: dinesh.botany@gmail.com; ijanarjeh@masdar.ac.ae;

(C) 2014 International Association for Sharing Knowledge and Sustainability

DOI: $10.5383 /$ swes.06.01.0001
} 
requiring electrical power or specialized equipment [11]. Additionally, the data provide an integration of deposition over the exposure period. It provides an integrated picture of air pollution levels of around the clock and it can also be used to monitor and control the success of environmental policies.

The specific biology of mosses enables them to receive and accumulate chemical substances predominantly from surrounding atmosphere without any selectivity parameter $[12,13]$. They do not have conductive strand and root system, means directly uptake air pollutants and represent it by each cell's individually [14]. Due to their accumulation potential they have been preferred in present study.

The advantages of the biological monitoring and bryophyte as compared with instrumental and chemical methods can be summarized as follows:

- Inexpensive compared to the instrumental monitoring. As the former needs number of instruments for deployment on each site to obtain trends in atmospheric metal deposition. This includes, uninterrupted power supply, operating manpower additional to maintenance.

- Involved large number of monitoring instruments making it inconvenient and cumbersome.

- Risk of environment hazardous for chemical monitoring.

While Mosses and liverworts do not take anything from substratum; on the contrary they take nutrient and moisture from air, fungi and algae cannot be inducted in monitoring as they lack the chlorophyll some times and algae strive in water hence not fit for ambient air monitoring. Additonally, pteridophytes, gymnosperm and angiosperm are rooted plants and therefore in their analysis represent the metals absorbed by root.

Why validations of metal tolerant moss essential?
It is desirable to know the tolerance potentials of mosses against metals before inducting in a monitoring programme. Since metal toxicity in sensitive moss species may impair its physiology and therefore will effect on accumulation potentials. To omit out sensitive moss species, it is desirable to validate the tolerant species against metals to induct in ambient metal monitoring program.

\section{Approach to validate the tolerant species}

Chlorophyll fluorescence measurements are best, non-invasive tool to test the status of health of plant during the stress in the field and laboratory. It can be performed quickly without the use of any chemicals. For inducting any moss species in bio-mapping program, measurement of status of health is desired to validate the tolerance against metals by measuring their chlorophyll fluorescence. Although the total amount of chlorophyll fluorescence is very small (only 1 or $2 \%$ of total light absorbed), the measurement can be accurately acquired. The spectrum of fluorescence is different to that of absorbed light, with the peak of fluorescence emission being of longer wavelength than that of absorption. Therefore, fluorescence yield can be quantified by exposing a leaf to light of defined wavelength and measuring the amount of light reemitted at longer wavelengths. For the first time PEA (photosynthetic efficiency analyzer) was applied to validate the tolerant species without in a non-invasive approach.

In present study, moss Racomitriumcrispulum (Hook. f. et Wils.) is attempted for the first time as an active bio-monitor to determine total and seasonal atmospheric deposition of metals in Kumaon hills during year 2004. Transplant technique is useful especially in such areas where identified or inducted moss is lacking in monitoring areas $[15,3]$.

\section{Materials and Methods}

\section{Study area}

The Kumaon region is spread over $21,073 \mathrm{Km}^{2}$ and had extensive track of natural forests until a few centuries back. The species is of wide range of distribution in Western Himalaya geographically ranging from $29^{\circ} 5^{\prime}-31^{\circ} 25^{\prime} \mathrm{N}$ in latitude to $79^{\circ} 43^{\prime}$ $81^{\circ} \mathrm{E}$ in longitude (IG, 1931). The Kumaon hill is extensively divided into three major zones for the bio-mapping study namely- Almora (E 79 $26^{\circ} \mathrm{E}$ to $80^{\circ} 15^{\prime} \mathrm{E}$ and $\mathrm{N} 29^{\circ} 15^{\prime} \mathrm{N}$ to $30^{\circ} 29^{\prime} \mathrm{N}$ ), Nainital (E $79^{\circ} 54^{\prime} \mathrm{E}$ to $80^{\circ} 18^{\prime} \mathrm{E}$ and $\mathrm{N} 28^{\circ} 45^{\prime} \mathrm{N}$ to $29^{\circ} 38^{\prime} \mathrm{N}$ ) and Pithoragarh (longitudes $79^{\circ} 45^{\prime} \mathrm{E}-81^{\circ} 21^{\prime} \mathrm{E}$; latitudes $29^{\circ} 32^{\prime} \mathrm{N}-30^{\circ} 47^{\prime} \mathrm{N}$ ).. It is characterized with a quite cold weather between October - April and mild warm through May - June followed by monsoon rain until September. The average measured rainfall is $80 \mathrm{in}$ and the relative humidity range from 85 to $90 \%$ in the months of July and August. The maximum and minimum recorded temperatures were $27^{\circ} \mathrm{C}$ to $10^{\circ} \mathrm{C}$ in summer and $15^{\circ} \mathrm{C}$ to $3^{\circ} \mathrm{C}$ in winter seasons.

\section{Sampling of moss species}

The collection of moss samples was carried out according to the guidelines of the UNECE ICP vegetation. The most dominant moss species in this study are Rhodobryumgiganteum (Schwaegr) Par., Rhynchostegielladivaricatifolia (Renauld\&Cardot) 
Broth., PohliaelongataHedw, Racomitriumcrispulum (Hook. f. et Wils.), Pleuroziumshcreberi, Hylocomiumsplendens, Hypnumcupressiforme, Brachytheciumrutabulum, Homalotheciumsericeum, Racomitriumcrispulum. Before any species inducted, each was validated for metal tolerance. For collection of each moss sample a separate set of disposable polyethylene gloves was used. Collected samples were stored in hygienic paper bags.

\section{Validation of metal tolerance species}

There are a number of physiological variables that can be used as vitality indicators. They may be based on: (1) photosynthetic pigment composition, i.e. chlorophyll concentration, chlorophyll a/b ratio, the quotient between absorbance at 430 and $410 \mathrm{~nm}$, and several others; (2) photosynthesis rates; and (3) chlorophyll fluorescence. Chlorophyll fluorescence is probably the most direct, non-invasive and fastest method. Out of available ten moss species only six widely distributed mosses were short listed because the other four species were not commonly available at all sites.

A handy photosynthetic efficiency analyzer (Handy PEA, Hansatech Instruments Model No. 1011) was used to validate the best metal tolerance moss amongst the considerec six mosses, including i.e. Rhodobryumgiganteum (Schwaegr.) Par, PohliaelongataHedw., Racomitriumcrispulum, Rhynchostegielladivaricatifolia (Renauld\&Cardot) Broth, Hylocomiumsplendens and Pleuroziumshcreberi by measuring their chlorophyll a fluorescence in the field. The moss beds were covered by plastic beljar stretching over $1 \mathrm{ft}^{2}$ after spraying known concentration of the solution. The ratio of variable $\left(\mathrm{F}_{\mathrm{v}}\right)$ to maximal fluorescence $\left(\mathrm{F}_{\mathrm{m}}\right)$ was measured at different intervals to indirectly evaluate the photosynthetic activity response to the metal treatment. This is written as:

$F_{v}=F_{m}-F_{o}$

Where $F_{m}$ and $F_{0}$, are the maximum and initial fluorescence, respectively. In other words, $F_{m}$ is the maximum chlorophyll $a$ fluorescence at the used light intensity whereas $F_{v}$ is related to the maximum capacity for photochemistry of Photosystem II (Govindjee 2004). The $F_{v} / F_{m}$ ratio has thus been considered as a sensitive indicator of plant photosynthetic efficiency/performance, with its maximum value being about $0.80-0.85$. A lower Value indicates impaired photosynthesis or it is an indication of stress. From our pilot study, it was evident that Racomitriumcrispulum is one of the metal tolerant species, thereby it is inducted for the purpose of bio-monitoring atmospheric metal as its photosynthetic efficiency was not impaired deeply as evident in the $F_{v} / F_{m}$ values compared to the other mosses as depicted in Fig.1.
30 minutes
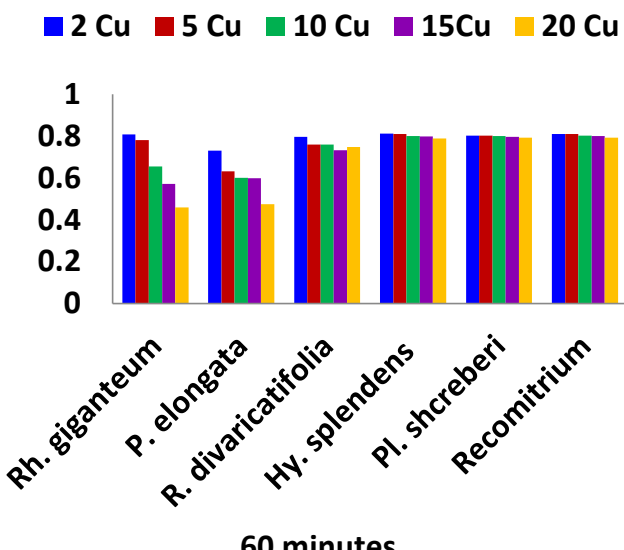

$\square 2 \mathrm{Cu}-5 \mathrm{Cu}-10 \mathrm{Cu}-15 \mathrm{Cu}-20 \mathrm{Cu}$

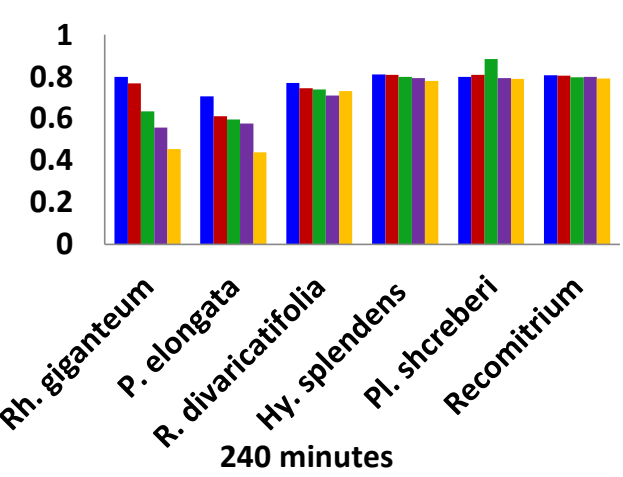

$-2 \mathrm{Cu}-5 \mathrm{Cu}-10 \mathrm{Cu} \square 15 \mathrm{Cu} \square 20 \mathrm{Cu}$

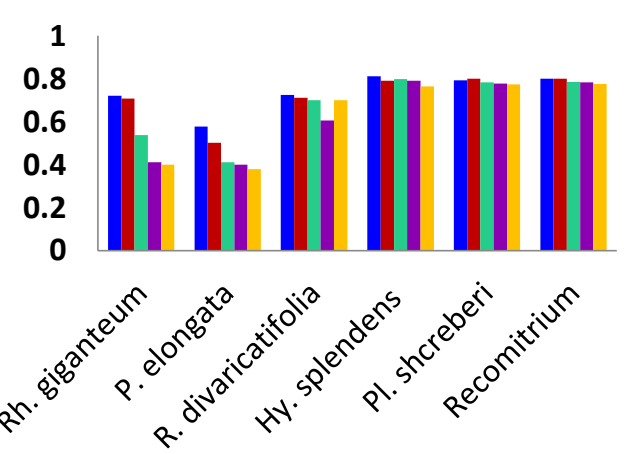

Fig. 1: Chlorophyll fluorescence value of different lead concentration tested against 5 moss species after 30,60 , and 120 minutes and

Ideally all six undertaken moss species should have been validated for all four metals $(\mathrm{Cu}, \mathrm{Pb} \mathrm{Cd}$, and $\mathrm{Zn}$ ) under consideration. Given $\mathrm{Cu}$ and $\mathrm{Zn}$ are essential trace elements and $\mathrm{Cd}$ is relatively less abundant in the atmosphere [16], it is not unreasonable to assume that $\mathrm{a} \mathrm{Pb}$ and $\mathrm{Cu}$ tolerant moss species will be also tolerate $\mathrm{Cd}$ and $\mathrm{Zn}$. 


\section{Moss transplants}

Validated tolerant moss Racomitriumcrispulum (Hook. f. et Wils.). was transplanted at a distance at least $1000 \mathrm{~m}$ from main roads. Each sample was composed of 5 to 10 sub-samples collected within an area of $50 \times 50 \mathrm{~m}$, in order to make the moss samples representative for a reasonably large area. A complete green patch of moss was transplanted in nylon bags at 19 study sites of the investigated area.

\section{Seasonal Meta Data}

Each moss bag was suspended at height of 8 feet above the ground in triplicate. These moss bags were transplanted in cross direction wise in all the four directions for a duration of four months (representing one season) and were harvested after an exposure in baseline metal load from Mukteswar site treated as control.

\section{Reagents and standards}

All of the reagents used for this study were with analytical grade of Nitric acid (Merck) $\left(\mathrm{HNO}_{3}\right)$, Perchloric acid (Merck) $\left(\mathrm{HClO}_{4}\right)$ and triple distilled water. Solutes used for preparing standard solutions was with concentration of $1000 \mathrm{mg} \mathrm{L}^{-1}$.

Upon return to the laboratory, harvested moss samples was oven dried at $40^{\circ} \mathrm{C}$ for 24 hours. Prior to analysis, adhering substrate and dirt was removed by hand and great care being taken to avoid metal contamination. For analysis sufficient amount of the exposed moss species harvested and was taken for digestion to determine the metals in each season. For the baseline metal load, moss from Mukteswar site was treated as control. Triplicate samples were digested with the concentrated $\mathrm{HNO}_{3}$ and $\mathrm{HClO}_{4}$ solutes in a ratio of $4: 1 \mathrm{v} / \mathrm{v}$ on a hot plate. The digestion was completed after all organic material had disappeared. The extract obtained was filtered and the filtrate was made up to a final volume of 50 $\mathrm{ml}$ by double distilled water and fraction was quantitatively analyzed using an atomic absorption spectrophotometer (flame type), the equipment having been previously calibrated (Model no. 4039). Suitable blank was used to check for possible contamination during extraction.

\section{Data analysis}

Samples were collected in triplicate to conduct the statistical analysis. Values were represented as mean + standard error [17]. The significance in metal concentration at different distances and seasons were calculated utilizing Dunkun's Multiple Range test [18].
A cartographic representation of the results was performed with the program package Surfer (Golden Software Inc., U. S. A.). Pollution index (PI) of the study area is calculated on the basis of each metal, total number of metals, total amounts of metals and number of samples collected from a predefined area of the district $[18,19]$. The formula of PI value is location specific and is defined as:

$P_{j}=\sum_{j=1}^{i=j} \frac{x_{i j}-\bar{x}_{i}}{\bar{x}_{i}}$

Where $x_{\mathrm{ij}}$ is the content of $i^{\text {th }}$ metal at $j^{\text {th }}$ location and $\bar{x}_{i}$ is the average of $i^{\text {th }}$ metal at all locations. The percentage of the metal load (ML) was calculated according to:

$M L(\%)=\left(\sum_{i=1}^{N} M_{T}-M_{T i}\right) / N \sum_{i=1}^{N} M_{T i}$

Where $\mathrm{M}_{\mathrm{T} 1}+\mathrm{M}_{\mathrm{T} 2} \ldots+\mathrm{M}_{\mathrm{Tj}}$ is the total metal $\mathrm{M}$ at all sites starting from $1^{\text {st }}$ to $\mathrm{N}$ site.

\section{Results}

\section{Metal tolerant moss}

Amongst 10 widely distributed mosses, six mosses (Racomitriumcrispulum,

Rhynchostegielladivaricatifolia (Renauld\&Cardot) Broth, Hylocomiumsplendens, Pleuroziumshcreberi, Rhodobryumgiganteum (Schwaegr.) Par, PohliaelongataHedw) were shortlisted on the basis of their wide distribution. Mosses were validated for metals tolerance using chlorophyll fluorescence signal, as these measurements gave more detailed insight into the function of the photosynthetic apparatus during metal treatment. This approach is noninvasive and was preferred. Results of the chlorophyll fluorescence measurements taken for these six mosses against different concentrations of metals suggests that Racomitriumcrispulum is a tolerant moss, as $F_{v} / F_{m}$ values were minimally affected as depicted in Figs. 1 and 2. Thereby, this specific moss was inducted in a monitoring program. 

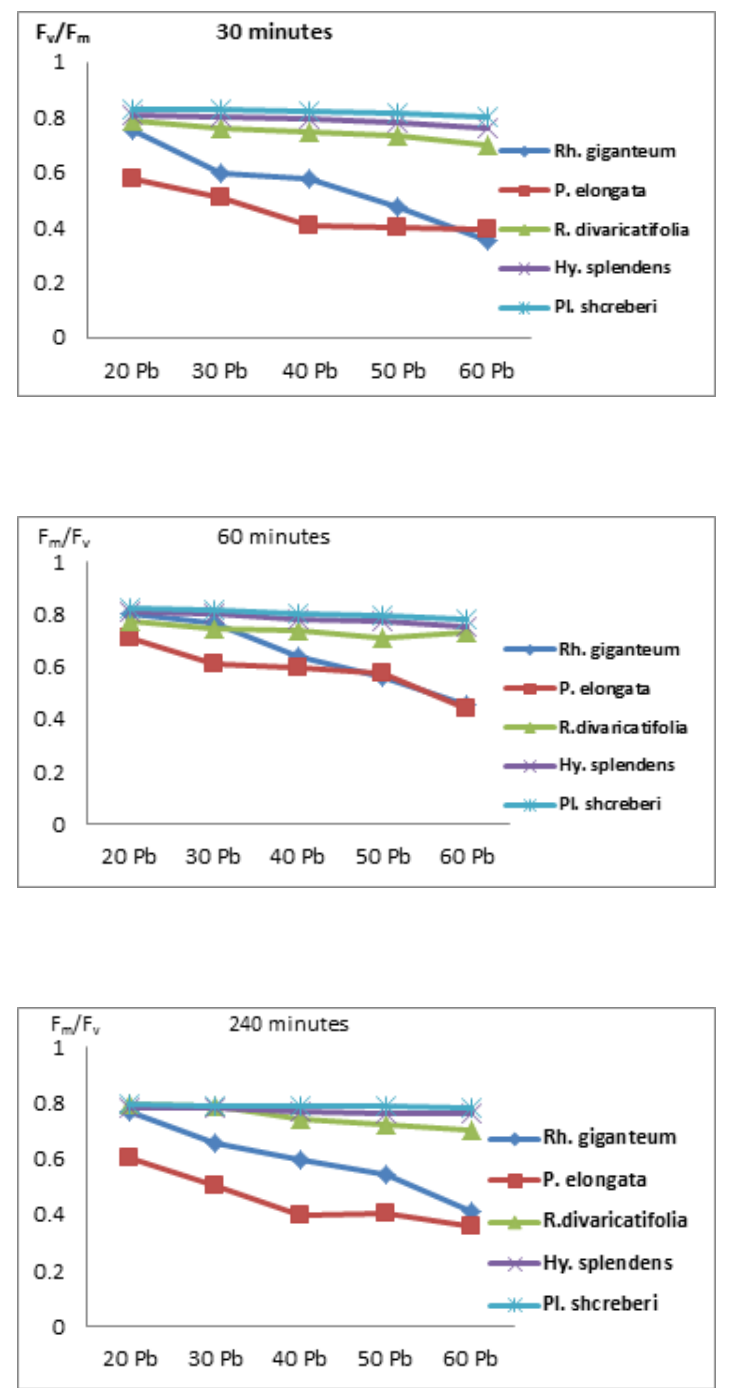

Fig. 2: Chlorophyll fluorescence value against metal lead tested against 5 moss species after 30, 60, and 120 minutes

\section{Metal Lead}

The mean value of each metal and its significance (ANOVA at $\mathrm{P} \leq 0.05$ and $\mathrm{P} \leq 0.01$ ) was calculated, along with its corresponding mean value at the Mukteswar control site. Amongst 19 catchments sites, the moss harvested from Nainital (bus stand) exhibited the maximum value of lead $\left(56.32 \mu \mathrm{g} \mathrm{g}^{-1}\right)$ while the minimum value was measured from moss from Mukteswar $\left(8.39 \mu \mathrm{g} \mathrm{g}^{-1}\right)$ during 2004 (see Table 1 at the end).

\section{Seasonal Pattern of metal Precipitation}

The seasonally exposed moss samples were analyzed for metals at different regions during the year 2004, as listed in Table 1 and depicted Figs. 3 to 5 at the end. High values were measured during summer and winter from the Nainital site, whereas during the monsoon high values were recorded from Almora. $\mathrm{Pb}$ concentration in moss Racomitriumcrispulum in experimental area also measured seasonally (Table 1). Seasonal trends for $\mathrm{Pb}$ for maximum values were in order for summer, winter and rain measured as 56.32, 42.11 and $18.06 \mu \mathrm{g} \mathrm{g}^{-1}$. Another important crowded hill station, Almora, led to values in order of $31.57,36.49$, and $18.06 \mu \mathrm{g} \mathrm{g}^{-1}$ during winter, summer and monsoon, respectively. The lowest $\mathrm{Pb}$ value was measured in moss Racomitriumcrispulumspecies harvested from Mukteswar forest of 12.34, 14.93 and $8.39 \mu \mathrm{g} \mathrm{g}^{-1}$ during winter, summer and monsoon seasons, respectively (Table 1). Both sites are heavily crowded during summer because of tourist inflow from all over the country. The overall percent metal $\mathrm{Pb}$ load did not exceed $8 \%$. At Nainital bus stand, Almora petrol pump and Ranikhet golf court had maximum percentage of metal $\mathrm{Pb}$ as depicted in fig. 6. It also shows that the Tallital and the bus stand area of Nainital characterized with maximum value of $\mathrm{Pb}$ deposition in Racomitriumcrispulum. During the monsoon, a decrease in $\mathrm{Pb}$ of approximately 61\% was noticed at Almora (Mall road). Moss from Pithoragarh area also exhibited high values for the lead, but were within the range of the 21.6, 27.95 and $14.08 \mu \mathrm{g} \mathrm{g}^{-1}$ during the summer, winter and in rain.

The high consumption of fuel during the tourist inflow could be the reason for the high lead value in all seasons except during rainy season, particularly along the roads and near the Nainital bus stand as depicted in Figs. 3a, 4a and 5a. This observation is in line with others, who have suggested that tourist places intensify vehicle pollution [20, 21]. The overall maximum percent metal $\mathrm{Pb}$ load in moss harvested from the locations of Nainital bus stand, Almora petrol pump and Ranikhetgolf court is in line with their maximum value, as depicted in Fig. 6. Another reason is due to mushroom growth in hotels and the unwise construction of houses that resulted in deforestation. Intensity further amplifies because of the increase in transportation mean to meet their daily needs. However, decrease in $\mathrm{Pb}$ load during monsoon at Mall road of Almora could be due to a low turnout in tourist activities and the wash out during rain (see Fig. 5a). Combustion of leaded gasoline continues to be the major source of atmospheric $\mathrm{Pb}$ emissions, and the present finding is in agreement with the report of Pacyna and Pacyna [22]. Even though low lead gasoline has been utilized, the high congestion and staggering emission still outweighs this factor[23].

\section{Metal Zinc}

The site measurement of $\mathrm{Zn}$ was high at Nainital during summer $91.83 \mu \mathrm{g} \mathrm{g}^{-1}$ followed by $56.34 \mu \mathrm{g} \mathrm{g}^{-1}$ in winters. During monsoon, however, and at Ranikhet (Golf court) and Ranikhet, the measured $\mathrm{Zn}$ was 66.32 , and $49.97 \mu \mathrm{g} \mathrm{g}^{-1}$, respectively. Measured $\mathrm{Zn}$ values in moss from the control side (Mukteswar) was 9.35 and $15.03 \mu \mathrm{g} \mathrm{g}^{-1}$ in winters 
and summer, respectively. Farming sites i.e. Dinapani, Kosi and Ranikhet (golf court) showed a significant increase in $\mathrm{Zn}(34 \%)$ during summer compared to winter, as shown in Fig. 6. The monsoon season exhibits completely different precipitation pictures for $\mathrm{Zn}$ in moss Racomitriumcrispulum. The sites of Almora (Mall road), Nainital (Bus stand) observed 31-43 \% reduction in $\mathrm{Zn}$ concentration with respect to summer during monsoon in Racomitriumcrispulum (Fig. 6). The control Mukteswar site showed a decrease of $18 \%$ in $\mathrm{Zn}$ during the rainy season compared to summer, as depicted in Fig. 6.

The increase in metal $\mathrm{Zn}$ measured in moss harvested from the same sites have a similar trend to that of $\mathrm{Pb}$, with regression correlation of $\mathrm{R}^{2}$ being 0.8781 in Almora and Pithoragarh. Locations close to orchards sites, such as Kosi and the Ranikhet golf court, are used to growing fruits, i.e. apples, peach, plums, pear and oranges, during summer, in which $\mathrm{Zn}$ is applied as a micronutrient. An increase in $\mathrm{Zn}$ in this area is amplified due to the fact that zinc is applied through foliar or aerial spray growth, promoting element [24].

The enrichment ratios for $\mathrm{Zn}$ in moss was not constant throughout the year, therefore, an interpretation of enrichment of $\mathrm{Zn}$ is complicated. A seasonal trend for metal $\mathrm{Zn}$ suggests that summers have high value of $\mathrm{Zn}$ followed by winters and rain, as depicted in Figs. 4b and 5b. Heavy rain fall could be another reason to explain the decrease in values. Aside from being a nutrient, farmers also implicate Zinc as $\mathrm{Zn}$ - based insecticides or fungicides [25]. Moderately high concentration of metal $\mathrm{Zn}$ was measured in moss harvested from tourist places i.e. Nainital (Tallital\& bus stand) and Almora (Mall road) during winter 2004, as listed Table 1. Here one cannot overrule the effect of traffic to increase $\mathrm{Zn}$ along the road, as it is the part of automobile stratum [26] additional to the wear and tear of automobile parts, as well as abrasion of tire.

\section{Metal Copper}

In comparison to $\mathrm{Pb}$ and $\mathrm{Zn}$, a moderate deposition rate of metal copper was observed from different catchment areas. Measured values of $\mathrm{Cu}$ in moss Racomitriumcrispulum was maximum $\left(25.64 \mu \mathrm{g} \mathrm{g}^{-1}\right)$ at the Nainital (Tallital) site and same was lowest at Pithoragarh in winters. On the contrary, values of copper were $37.04 \mu \mathrm{g} \mathrm{g}^{-1}$ in transplant moss harvested from the Nainital Bus stand during summer and low again from Pithoragarh. Almost the same trend was seen in monsoon (see Table 1 at the end).

The comparative study on the seasonal basis revealed that summer is the season for high $\mathrm{Cu}$ load in moss and lowest in monsoon. A total decrease of $24 \%$ was measured in $\mathrm{Cu}$ content from moss Racomitriumcrispulum from catchment areas of Nainital during winter with respect to 2004 summer. Present findings deployed that Ranikhet golf court and Almora (petrol pump) exhibited a decrease of $94 \%$ and $81 \%$ in metal $\mathrm{Cu}$ during winter season with reference to summer in the year 2004. The catchment area of Almora (mall road) exhibited a decrease in $\mathrm{Cu}$ of $43 \%$ in the rainy season in reference to summer (Fig. 6). A decrease in $\mathrm{Cu}$ in winter with respect to summer could be explained by considering that dry deposition increases on moving from arid to humid climates [27] (Coutoet al., 2004). A maximum value of copper was in Almora during summer and in Nainital in winter seasons, as listed in table 1 .

Metal $\mathrm{Cu}$ was high in rural areas (see Figs. 3c, 4c and 5c) in comparison to urban areas, which could be due to its applications as copper based insecticides and pesticides. Present findings are also further supported by the presence of $\mathrm{Cu}$ mosses in these areas [26].

Concentration and distribution patterns of both metals $\mathrm{Zn}$ and $\mathrm{Cu}$ in moss Racomitriumcrispulum were quite similar and both metals were high in moss of rural transplants located in vicinity of orchards. $\mathrm{Cu}$ contamination mainly originates from fertilizers, fungicides and pesticides used in agricultural areas [26, 28]. A significant correlation was found between $\mathrm{Zn}$ and $\mathrm{Cu}$ content $\left(\mathrm{R}^{2}=0.8804\right)$ in Racomitriumcrispulum species of Kumaon hill as listed in table 2. $\mathrm{Cu}$ pollution may also originate from domestic waste disposal. The use of $\mathrm{CuSO}_{4}$ mixed kerosene oil could also be one of the facts of increase of $\mathrm{Cu}$ concentration in domestic areas.

Table 2: Correlation coefficients amongst metal concentration in Kumaon Hill (India) through active monitoring in year 2004 using Racomitrium

crispulum as a biomonitoring species.

\begin{tabular}{ccccc}
\hline & $\mathrm{Pb}$ & $\mathrm{Zn}$ & $\mathrm{Cu}$ & $\mathrm{Cd}$ \\
\hline $\mathrm{Pb}$ & 1.0000 & & & \\
$\mathrm{Zn}$ & 0.8781 & 1.0000 & & \\
$\mathrm{Cu}$ & 0.6113 & 0.8804 & 1.0000 & \\
$\mathrm{Cd}$ & 0.4618 & 0.5801 & 0.4236 & 1.0000 \\
\hline
\end{tabular}

\section{Metal cadmium}

On the basis of indirect method of metal distribution study, analyzed moss samples were found to have a somewhat higher amount of Cd from Jageshwar and from the agricultural areas of Kosi. During winter, a high value of $\mathrm{Cd}$ was measured in transplants of moss harvested from Ranikhet (petrol pump). In winter season there was around $83.31 \%$ increase in $\mathrm{Cd}$ at the Ranikhet golf court in winter with respect to summer, which a striking outcome (Fig. 6). 
Cadmium metal is very easily leached out from surface and the similar results were observed in monsoon season in moss Racomitriumcrispulum. All catchment areas show significant $(\mathrm{P} \leq 0.01)$ decrease in metal $\mathrm{Cd}$ value in rainy season with respect to summer (Table 1). Easily leaching property could be the reason for their low value even in the forest areas, [29] but a different experiment of $\mathrm{Cd}$ adsorption on surface reports that kinetics study for the rate of adsorption is also an important factor to consider before commenting on leaching property $[30,31]$. There is frequent use of breaks in the hilly region compare to the land areas. This could be the reason for high value of $\mathrm{Cd}$ at Ranikhet (petrol pump) in winter 2004 (Fig. 4d). An increase in the $\mathrm{Cd}$ on such places could be from abrasion of clutch, breaks of the vehicles. Higher concentrations in moss from an agricultural land might be due to the use of phosphate fertilizers [25, 26 and 31].

\section{Percent metal load and pollution index value}

Nainital (Tallital) had maximum percent metal loading i.e. $6.33 \%$ during year 2004 (Fig. 6). This could be explained by taking into consideration the internal environment factors, such as meta-data influencing the metal deposition. In addition, converting the value measured in bio-monitor into deposition value is problematic, because there is not enough information available about the factor affecting the concentration in mosses $[2,31]$.

The pollution index (PI) value at the Nainital bus stand, Almora mall road, Kosi, Almora petrol pump, Ranikhet petrol pump and Pithoragarh market area was $+1.102393,+1.012493,+1.075294,+1.109318$, +1.013296 and +1.000281 , respectively during year 2004 as listed in Table 3. In present study, Mukteswar forest was considered a control site. The least value of percent metal load at Mukteswar deploys that our consideration of taking Mukteswar as control site is significant (Fig. 6). The pollution index (PI) value at Nainital bus stand, Almora mall road, Kosi, Almora petrol pump, Ranikhet petrol pump and Pithoragarh market area was +1.102393 , $+1.012493,+1.075294,+1.109318,+1.013296$ and +1.000281 , respectively during year 2004 and is tabulated in table 3. At Mukteshwar the PI value was recorded as -1.73241 .

Table 3: Comparison PI value of by using moss Racomitrium crispulum as a biomonitoring species exposed in Kumaon hills.

\begin{tabular}{lr}
\hline Catchment Sites & $\begin{array}{c}\text { Year } \\
\text { (2004) }\end{array}$ \\
\hline Mukteswar forest & -1.73241 \\
Deenapnai & 0.13038 \\
Jageswar & -0.59865 \\
Hwalbagh & 0.34087 \\
Almora (Mall road) & 1.012493 \\
Kosi (G.B. Pant inst.) & 1.075294 \\
Almora (Petrol pump) & 1.109318 \\
Ranikhet (Golf court) & 0.020039 \\
Ranikhet( Bus stand) & 0.100131 \\
Ranikhet ( Petrol pump) & 1.013296 \\
Nainital ( Bus stand) & 1.102393 \\
Nainital(Mallital) & 0.723167 \\
Nainital (Tallital) & 0.209319 \\
Nainital (Capitol cinema) & 0.912817 \\
Bhowali ( Bus stand) & 0.931823 \\
Ramgarh (Ramgarh malla) & 0.052352 \\
Pithoragarh (Siltham) & 0.101013 \\
Pithoragarh (Market area) & 1.000281 \\
Pithoragarh (Bus stand) & 0.142591 \\
\hline
\end{tabular}

The major anthropogenic pollutant released is $\mathrm{Cd}$ and $\mathrm{Cu}$ from phosphate fertilizers [25, 32] Amundsen et al., 2000. Phosphate fertilizers contain 5-100 mg Cd Kg ${ }^{-1}$ and excessive use of this metal will decrease the natural fertility rate of soil. $\mathrm{Zn}$ is chemically similar to $\mathrm{Cd}$; it is also readily taken up by plants and enters edible portions which is a major concern for the edibility of foods such as grains and vegetables. Although $\mathrm{Pb}$ is not easily accumulated by plants, their presence in excessive in environments like as organo-lead compounds e.g., alkyl lead (from automobiles) are highly toxic, even when they occur at very low concentrations [33]. However, excessive concentrations analyzed in transplants of mosses indicates that these hills stations are also victims of the elevated atmospheric metal concentrations due to poor policies, unwise constructions and heavy vehicular traffic which are the only mode of transportation for the public and supply daily needs $[6,34]$.

The pollution index (PI) value was highly positive at the areas near the bus stand and at petrol pumps. This was further supported by percent metal loading in respective locations during these years. The maximum positive values were measured in proximity to the city area. Negative value at Mukteshwar forest reveals that it is a relatively cleaner site. The effect of intensity of traffic compared to the influence of other factors such as farming on sampling points are much higher, as the spots were nearer to the roads (except control site). Besides this, contamination was high and reduces with distance [23].

In conclusion, the present research gives supportive evidence of metal pollution on Kumaon hills. Elemental concentration in Racomitriumcrispulum was in order $\mathrm{Zn}>\mathrm{Pb} \sim \mathrm{Cu}>\mathrm{Cd}$ in summer, while the same was $\mathrm{Zn}>\mathrm{Cu}>\mathrm{Pb}>\mathrm{Cd}$ in winter season and in rain $\mathrm{Zn}>\mathrm{Cu}>\mathrm{Pb}>\mathrm{Cd}$ indeed reflects atmospheric trace elemental load. Amongst season summer deployed maximum metal load followed by winter and monsoon. Present findings describe that Nainital 
is most polluted for heavy metal $(\mathrm{Pb}, \mathrm{Zn}, \mathrm{Cu}$ and Cd), followed by Almora and Pithoragarh. Present funded study of ministry of Environment, Government of India, is very useful for a policy maker to take the necessary steps for control measure on Himalayan belt, which directly reflects the weather condition of north India.

\section{Conclusion}

A moss bio-monitoring technique was used for quantification of under taken metals in the air from Kumaon regions. Higher values of the element were measured in moss transplants harvested from the study regions in proximity to the road and from the center of tourist cities. Inter-seasonal variability in metal value depicts that for active monitoring, tolerant and widely distributed moss can be used as bio monitor. Value of percent metal load at Nainital (Tallital) during experimental year 2004 was very significant. Values measured were high in moss during summer, followed by the winter samples. Higher contents of this element were found in moss

\section{References}

[1] Markert, B., Wappelhorst, O.,Weckert, V., Herpin, U., Siewers, U., Friese, K., Breulmann, G. The use of bioindicators for biomonitoring the heavy-metals status of the environment. J. Radioanal. Nuclear chem. 1999, 240 (2):425-429.

[2] Poikolainen, J., Kubin, E., Piispanen, J., Karhu, J. Atmospheric heavy metal deposition in Finland during 1985-2000 using mosses as bioindicators. 2004, Sci. total. Environ,318: 171-185.

[3] Saxena, D K, Hooda, P. S., Singh S., Srivastava, K.,Kalaji, H. M.,Gahtori, D. An assessment of atmospheric metal deposition in Garhwal Hills, India by moss Rhodobryumgiganteum (Scchwaer.) Par. Geophyology. 2013, 43 (1): 17-28.

[4] Saxena D. K., Srivastava, K., Singh, S. Retrospective metal data of the last 100 years deduced by moss, Barbulasp. from Mussoorie city, Garhwal Hills, India. Curr. Sci., 2008a., 94 (7): 901 904.

[5] Soleimani, M, Rafinejad, J. House Dust mite Contamination in Hotels and Inns in Bandar Abbas, south of Iran. Iran. J. Environ. Health. Sci. Eng., 2008, 5 (3): 207-210.

[6] Halleraker, J. H., Reimann, C., Caritat, P. de., Finne, T. E., Kashulina, F.,Niskaavaara, H. samples collected in the regions of central city sites. By comparing median values from this and previous study (2004), it was observed that the content of metals had an increasing trend. Two types of petroleum distillates are used in gasoline-powered automotive vehicles. One contains $0.63 \mathrm{~g} \mathrm{l}^{-1}$ of lead while 'Regular' contains $0.42 \mathrm{~g} \mathrm{l}^{-1}$ of lead. The consumption of super graded petrol is higher than that of regular grade. It could be concluded from the above figures that burning of gasoline with high lead content is the main cause of the high levels of lead in particulate deposits collected from different designated sites in the study area.

\section{Acknowledgements}

The authors acknowledge the support from the Department of Biotechnology, Ministry of Science and Technology, Govt. of India (Grant BT/PR3 108/BCE/08/235/2002). Authors also would like to thank the Ministry of Environment and Forest (19/13/08-RE) for their support to carry out present work. Finally, authors like to acknowledge the support of Masdar Institute for the collaborative research opportunity.

Bogatyrev I., Reliability of moss (Hylocomiumsplendens and Pleuroziumshcreberi) as a bioindicator of atmospheric chemistry in the Barents region: Interspecies and field duplicate variability. Sci. total.Environ., 1998,218: 123-139.

[7] Bargagli, R. Trace elements in terrestrial plants, Anecophysiological approach to biomonitoring and biorecovery. Springer Verlag, Berlin, New York, 1998, pp 324.

[8] Saxena, D. K., Singh, S., Srivastava, K.Atmospheric Heavy Metal Deposition in Garhwal Hill Area (India): Estimation Based on Native Moss Analysis.Aerosol and Air Quality Research., 2008b, 8(1): 94-111.

[9] Sardans, J., Peňuelas, J., Trace element accumulationin the moss HypnumcupressiformeHedw. and the trees Quercus ilex L., and Pinushalepensis Mill. in Catalonia. Chemosphere.2005, 60: 1293-1307.

[10] Sun, S. Q., Wang, D. Y., He M., Zhang, C. Monitoring of atmospheric heavy metal deposition in Chongqing, China-based on moss bag technique. Environ. Monit. Assess. 2009. 148(1-4): 1-9.

[11] Saxena D. K., Arfeen, M. S.Effect of $\mathrm{Cu}$ and Cd on Oxidative enzymes and chlorophyll content of 
moss Racomitriumcrispulum.Taiwania. 2009,54 (4): 365-374.

[13] Fernandez, J. A., Aboal, J. R., Caballeira, A. Identification of pollution sources by means of moss bags. Ecotoxicology and Environmental Safety, 2004, 59 (1): 76-83.

[14]Glime, M. J., Saxena, D. K. 'Uses of Bryophytes'. Today \& Tomorrow's Printers \& Publisher, 1991, N. Delhi, India: 1-100.

[15] Makholm, M. M., Miladenoff David, J. Efficacy of a biomonitoring (moss bag) technique for determining element deposition trends on a mid range $(37 \mathrm{Km})$ scale. Environmental Monitoring and Assessment.2005, 104: 1-18.

[16] Hooda, P S Trace elements in soil. Blackwell Publishing Ltd, Chichester, 2010, U. K.

[17] Snedecor, G. W., Cochran, W. G. Statistical methods. Lowa State University, U. S. A. Oxford and I. B. H. Publishing Co., 1967, New Delhi.

[18] Karmer, C. Y. Extension of multiple range tests to group means with unequal numbers of replication. Biometrics, 1956, 12: 307-310.

[19] Grodzinska K., Godzik, B., Sjarek, G. Heavy metals and sulphur in moss from southern Spitsbergen. FrogmentaFloristicaEtGeobotanica. 1993,2(2): 699-708.

[20] Thoni, L., Schnyder, N., Krieg, F. Comparison of metal concentrations in three species of mosses and metal freights in bulk precipitations. Fresenius' Journal of Analytical Chem., 1996, 354: 704-708.

[21] De Caritat, P., Reimann, C., Bogatyrev, I., Chekuskin, V., Finn, TE, Halleraker, JH Kashulina, G., Niskavaara, H., Pavlov, V., Ayras, M. Regional distribution of $\mathrm{Al}, \mathrm{B}, \mathrm{Ba}, \mathrm{Ca}, \mathrm{K}, \mathrm{La}, \mathrm{Mg}, \mathrm{Mn}, \mathrm{Na}, \mathrm{P}$, $\mathrm{Rb}, \mathrm{Si}, \mathrm{Sr}, \mathrm{Th}, \mathrm{U}$ and $\mathrm{Y}$ in terrestrial moss within a $188,000 \mathrm{~km}^{2}$ area of the central Barents region: influence of geology, sea spray and human activity. Applied Geochemistry, 2001, 16: 137-159.

[22] Pacyna, J. M., Pacyna, E. G. Sources of heavy metals, inventories and future scenarios. Second AMAP International Symposium on Environmental Pollution of the Arctic.2002, Rovaniemi, O-006.

[23] Tuba, Z., Csintalan, Zs., Nagy, Z., Szente, K., Takács, Z. Sampling of terricolous lichen and moss
[12] Yurukova L., Gecheva G. Active and passive biomonitoring using Fontinalisantipyretica in Maritsa River, Bulgaria. J. of Balkan Ecol. 2003, 6 (4): 390-397.

species for trace element analysis with special reference to bioindication of air pollution. In: Markert B (Ed): Sampling of environmental materials for trace analysis, 415-434. VHC Publisher, 1994.Weinheim, New York, Tokyo.

[24] Molina, M., Aburto, F., Calderon, R., Cazanga, M., Escudey, M. Trace Element Composition of Selected Fertilizers Used in Chile: Phosphorus Fertilizers as a Source of Long-Term Soil Contamination. Soil and Sediment Contamination, 2009, 18 (4): 497-511.

[25] Singh, B. R., Almes, E., Amundsen, C. E., Meltzer, H. M., Alexander, J. Cadmium in fertilizers; soil-plant system, environment and human health. Norwegian Agricultural Inspection Service, N-140 Es, 1999. Norway.

[26] Bates, J. W. Mineral nutrient acquisition and retention by bryophytes. - J. Bryol., 1992, 17:223240.

[27] Couto, J. A., Aboal, J. R., Fernandez, J. A., Carballeira, A. A new method for testing the sensitivity of active biomonitoring: an example of its application to a terrestrial moss, Chemosphere, 2004, 57(4): 303-308.

[28] Otvos, E., Pazmandi, T., Tuba, Z.First national survey of atmospheric heavy metal deposition in Hungary by the analysis of mosses. Sci. total.Environ.,309: 151-160.

[29] Fernández, J. A.,Aboal, J. R., Carballeira, A. Testing differences in methods of preparing moss samples. Effect of washing on Pseudoscleropodiumpurum. Environ. Monit. Assess. 2009, ISSN 1573-2959 (Online).

[30] Izanlo, H., Nasseri S. Cadmium Removal from Aqueous Solutions by Ground Pine Cone. Iranian J Env Health SciEng, 2005, 2(1): 33-42.

[31] Berg, T., Hjellbrekke, A., Rühling, Á., Steinnes, E., Kubin, E., Larsen, M.M., Piispanen, J. Absolute deposition maps of heavy metals for the Nordic countries based on moss surveys. 2003, TemaNord, 505:pp 36.

[32] Amundsen, C. E., Almes, E., Singh, B. R. Cadmium in soil, soil solution, and plants.Data as basis of risk assessment of $\mathrm{Cd}$ in mineral fertilizers.Jordforsk-report 1/2000.Center for Soil 
and Environmental Research.2000, Frederik A. Dahlsvei 20, N-1430 Es, Norway.

[33] Fergusson, J. E. The heavy elements: Chemistry, Environmental impact and health effect. Pergamon press, New York, 1990, pp. 429-457.

[34] Fernández, J.A., Ederra, A., Nǔńez, E., Martinez-Abaigar, J., Infante, M., Heras, P., Elias, M. J., Mazimpaka, V., Carballeira, A. Biomonitoring of metal deposition in northern Spain by moss analysis. Sci. total.Environ., 2002 
Table 1. Metals Pb concentration ( $\mu \mathrm{g} \mathrm{g}^{-1} \mathrm{D} . \mathrm{wt}$.) $\pm \mathrm{SE}$ in seasonally exposed moss samples of Racomitrium crispulum at Kumaon hills (2004). Significance

\begin{tabular}{|c|c|c|c|c|c|c|c|c|c|c|c|c|}
\hline \multirow[t]{2}{*}{ Catchment sites } & \multicolumn{4}{|c|}{ WINTER 2004} & \multicolumn{4}{|c|}{ SUMMER 2004} & \multicolumn{4}{|c|}{ MONSOON 2004} \\
\hline & $\mathbf{P b}$ & $\mathbf{Z n}$ & $\mathrm{Cu}$ & Cd & $\mathbf{P b}$ & $\mathbf{Z n}$ & $\mathrm{Cu}$ & $\mathbf{C d}$ & $\mathbf{P b}$ & $\mathbf{Z n}$ & $\mathrm{Cu}$ & Cd \\
\hline Mukteswar forest & $12.34 \pm 0.92$ & $09.35 \pm 1.05$ & $11.34 \pm 0.91$ & $2.36 \pm 0.25$ & $14.93 \pm 0.94$ & $15.03 \pm 1.55$ & $13.83 \pm 0.91$ & $3.02 \pm 0.34$ & $8.39 \pm 0.81$ & $07.90 \pm 0.97$ & $09.86 \pm 0.97$ & $1.65 \pm 0.15$ \\
\hline Deenapnai & $20.34^{\mathrm{a}} \pm 1.04$ & $32.06^{\mathrm{a}} \pm 2.22$ & $8.37 \pm 0.86$ & $6.5^{\mathrm{a}} \pm 0.64$ & $27.45^{\mathrm{a}} \pm 1.76$ & $43.60^{\mathrm{a}} \pm 3.62$ & $11.38^{\mathrm{b}} \pm 0.91$ & $8.32^{\mathrm{a}} \pm 0.87$ & $13.83 \pm 0.91$ & $28.21^{\mathrm{a}} \pm 1.89$ & $7.28^{\mathrm{b}} \pm 0.72$ & $4.55^{\mathrm{a}} \pm 0.42$ \\
\hline Jageswar & $14.95^{\mathrm{b}} \pm 0.94$ & $36.29 \pm 2.65$ & $9.34^{\mathrm{b}} \pm 0.94$ & $1.23^{\mathrm{b}} \pm 0.15$ & $18.68 \pm 0.98$ & $46.08^{\mathrm{a}} \pm 3.62$ & $11.76^{\mathrm{b}} \pm 0.91$ & $1.57 \pm 0.15$ & $10.16^{\mathrm{b}} \pm 0.91$ & $31.93^{\mathrm{a}} \pm 2.12$ & $8.12^{\mathrm{b}} \pm 0.83$ & $0.86^{\mathrm{b}} \pm 0.03$ \\
\hline Hwalbagh & $15.37 \pm 0.95$ & $23.34 \pm 1.34$ & $11.67^{b} \pm 0.91$ & $0.12 \pm 0.05$ & $18.44 \pm 0.98$ & $28.47 \pm 1.81$ & $14.12^{\mathrm{b}} \pm 0.94$ & $0.15 \pm 0.05$ & $10.45^{\mathrm{b}} \pm 0.90$ & $20.52 \pm 1.03$ & $10.15^{\mathrm{b}} \pm 0.90$ & $0.08 \pm 0.01$ \\
\hline Almora (Mall road) & $16.24^{\mathrm{a}} \pm 0.96$ & $30.67^{\mathrm{a}} \pm 2.02$ & $11.24 \pm 0.91$ & $2.77 \pm 0.22$ & $25.82 \pm 1.51$ & $49.37^{\mathrm{a}} \pm 3.94$ & $18.20^{\mathrm{a}} \pm 0.92$ & $3.54^{\mathrm{b}} \pm 0.34$ & $11.04 \pm 0.91$ & $26.98^{\mathrm{a}} \pm 1.61$ & $9.77^{\mathrm{b}} \pm 0.92$ & $1.93 \pm 0.15$ \\
\hline Kosi (G.B. Pant institute) & $15.33 \pm 0.95$ & $40.37^{\mathrm{a}} \pm 3.05$ & $12.31^{\mathrm{b}} \pm 0.92$ & $6.28^{\mathrm{a}} \pm 0.61$ & $20.23^{\mathrm{a}} \pm 1.02$ & $53.69^{\mathrm{a}} \pm 4.35$ & $16.44 \pm 0.96$ & $8.03^{\mathrm{a}} \pm 0.85$ & $10.42^{\mathrm{b}} \pm 0.910$ & $35.52^{\mathrm{a}} \pm 2.55$ & $10.70^{\mathrm{b}} \pm 0.90$ & $4.39 \pm 0.42$ \\
\hline Almora (Petrol pump) & $31.57^{\mathrm{a}} \pm 1.16$ & $45.26^{\mathrm{a}} \pm 3.50$ & $12.38^{\mathrm{b}} \pm 0.92$ & 35 & $36.49^{\mathrm{a}} \pm 2.62$ & $62.91^{\mathrm{a}} \pm 5.25$ & $17.04 \pm 0.91$ & $4.62^{\mathrm{b}} \pm 0.45$ & $18.06^{\mathrm{a}} \pm 0.98$ & $39.82^{\mathrm{a}} \pm 2.93$ & $10.77^{\mathrm{b}} \pm 0.90$ & 20 \\
\hline Ranikhet (Golf court) & $21.64^{\mathrm{a}} \pm 1.11$ & $60.94^{\mathrm{a}} \pm 5.02$ & $8.34 \pm 0.81$ & $3.23 \pm 0.32$ & $30.07^{\mathrm{a}} \pm 2.01$ & $86.53^{\mathrm{a}} \pm 7.64$ & $11.74^{\mathrm{b}} \pm 0.91$ & $4.26^{\mathrm{b}} \pm 0.44$ & $15.14^{\mathrm{a}} \pm 0.91$ & $49.97^{\mathrm{a}} \pm 3.94$ & $6.58 \pm 0.63$ & $2.16 \pm 0.21$ \\
\hline Ranikhet( Bus stand) & $16.34^{\mathrm{a}} \pm 0.96$ & $54.36^{\mathrm{a}} \pm 4.44$ & $8.67 \pm 0.82$ & $2.12^{\mathrm{b}} \pm 0.24$ & $21.24 \pm 1.91$ & $71.75^{\mathrm{a}} \pm 6.12$ & $11.68^{\mathrm{b}} \pm 0.91$ & $2.79 \pm 0.25$ & $11.43^{\mathrm{b}} \pm 0.91$ & $44.57^{\mathrm{a}} \pm 3.46$ & $6.84 \pm 0.64$ & $1.42 \pm 0.14$ \\
\hline Ranikhet ( Petrol pump) & $22.34^{\mathrm{a}} \pm 1.94$ & $66.32^{\mathrm{a}} \pm 5.52$ & $10.38^{\mathrm{b}} \pm 0.90$ & $4.14 \pm 0.45$ & $31.05 \pm 2.12$ & $86.87^{\mathrm{a}} \pm 7.69$ & $14.03^{\mathrm{b}} \pm 0.94$ & $5.46^{\mathrm{a}} \pm 0.57$ & $15.63^{\mathrm{a}} \pm 0.95$ & $54.38^{\mathrm{a}} \pm 4.54$ & $8.20 \pm 0.85$ & $2.77 \pm 0.22$ \\
\hline Nainital ( Bus stand) & $42.11^{\mathrm{a}} \pm 1.62$ & $56.34^{\mathrm{a}} \pm 4.62$ & $22.87^{\mathrm{a}} \pm 1.21$ & $1.24^{\mathrm{b}} \pm 0.14$ & $56.32 \pm 3.31$ & $91.83^{\mathrm{a}} \pm 8.14$ & $37.04^{\mathrm{a}} \pm 2.74$ & $1.64 \pm 0.15$ & $17.03^{\mathrm{a}} \pm 1.90$ & $50.70^{\mathrm{a}} \pm 4.03$ & $18.29^{\mathrm{a}} \pm 0.98$ & $0.79^{b} \pm 0.04$ \\
\hline Nainital(Mallital) & $16.38^{\mathrm{a}} \pm 0.96$ & $45.67^{\mathrm{a}} \pm 3.54$ & $16.39^{\mathrm{a}} \pm 0.96$ & $0.96 \pm 0.02$ & $23.42^{\mathrm{a}} \pm 1.93$ & $66.22^{\mathrm{a}} \pm 5.62$ & $23.60^{\mathrm{a}} \pm 1.36$ & $1.27 \pm 0.12$ & $12.44 \pm 0.92$ & $41.10^{\mathrm{a}} \pm 3.11$ & $13.11 \pm 0.93$ & $0.61^{\mathrm{b}} \pm 0.02$ \\
\hline Nainital (Tallital) & $12.37^{\mathrm{b}} \pm 0.92$ & $80.34^{\mathrm{a}} \pm 7.01$ & $25.64^{\mathrm{a}} \pm 1.52$ & $1.23^{\mathrm{b}} \pm 0.14$ & $17.31 \pm 0.97$ & $114.08^{\mathrm{a}} \pm 11.45$ & $36.66^{\mathrm{a}} \pm 2.62$ & $1.63 \pm 0.14$ & $9.40^{\mathrm{b}} \pm 0.91$ & $72.30^{\mathrm{a}} \pm 6.23$ & $20.51^{\mathrm{a}} \pm 1.04$ & $0.78^{\mathrm{b}} \pm 0.04$ \\
\hline Nainital (Capitol cinema) & $14.22^{\mathrm{b}} \pm 0.92$ & $34.95^{\mathrm{a}} \pm 2.44$ & $10.99^{\mathrm{b}} \pm 0.90$ & $4.22 \pm 0.42$ & $18.77 \pm 0.81$ & $46.48^{\mathrm{a}} \pm 3.63$ & $14.72^{\mathrm{b}} \pm 0.94$ & $5.61 \pm 0.55$ & $10.80^{\mathrm{b}} \pm 0.91$ & $31.45^{\mathrm{a}} \pm 2.15$ & $8.79^{b} \pm 0.83$ & $2.70 \pm 1.72$ \\
\hline Bhowali ( Bus stand) & $15.38 \pm 0.95$ & $34.12^{\mathrm{a}} \pm 2.41$ & $12.87 \pm 0.92$ & $3.18 \pm 0.34$ & $22.60^{\mathrm{a}} \pm 1.22$ & $50.83^{\mathrm{a}} \pm 4.03$ & $19.04^{\mathrm{a}} \pm 0.96$ & $4.22 \pm 0.45$ & $11.68 \pm 0.91$ & $30.70^{\mathrm{a}} \pm 2.05$ & $10.29 \pm 0.90$ & $2.03 \pm 0.24$ \\
\hline Ramgarh malla & $15.64 \pm 0.95$ & $40.29^{\mathrm{a}} \pm 3.05$ & $12.64 \pm 0.92$ & $1.25^{\mathrm{b}} \pm 0.12$ & $20.33^{\mathrm{a}} \pm 1.01$ & $53.18^{\mathrm{a}} \pm 4.35$ & $16.82 \pm 0.96$ & $1.66 \pm 0.15$ & $11.88 \pm 0.91$ & $36.26^{\mathrm{a}} \pm 2.66$ & $10.11 \pm 0.90$ & $0.80^{\mathrm{b}} \pm 0.82$ \\
\hline Pithoragarh (Siltham) & $14.27^{b} \pm 0.94$ & $34.6^{\mathrm{a}} \pm 2.41$ & $12.37 \pm 0.92$ & $2.56 \pm 2.15$ & $17.14 \pm 0.97$ & $42.29^{\mathrm{a}} \pm 3.26$ & $15.21 \pm 0.95$ & $3.07^{\mathrm{b}} \pm 0.34$ & $9.27^{\mathrm{b}} \pm 0.91$ & $28.08^{\mathrm{a}} \pm 1.81$ & $09.27^{\mathrm{b}} \pm 0.93$ & $1.99 \pm 0.14$ \\
\hline Pithoragarh ( & $21.6^{\mathrm{a}} \pm 1.22$ & $60.25^{\mathrm{a}} \pm 5.04$ & $07.98 \pm 0.74$ & $5.17^{\mathrm{a}} \pm 0.51$ & $27.95^{\mathrm{a}} \pm 1.72$ & $79.53^{\mathrm{a}} \pm 6.94$ & $10.48^{\mathrm{b}} \pm 0.90$ & $6.20^{\mathrm{a}} \pm 0.65$ & $14.08 \pm 0.94$ & $48.80^{\mathrm{a}} \pm 3.82$ & $05.98 \pm 0.52$ & $4.03^{\mathrm{a}} \pm 0.35$ \\
\hline Pithoragarh (Bus stand) & $16.97 \pm 1.61$ & $20.35^{\mathrm{b}} \pm 1.05$ & $07.64 \pm 0.72$ & $2.36 \pm 0.23$ & $22.40^{\mathrm{a}} \pm 1.21$ & $25.03^{\mathrm{b}} \pm 1.55$ & $10.12^{\mathrm{b}} \pm 0.90$ & $2.83^{b} \pm 0.25$ & $11.03^{\mathrm{b}} \pm 0.91$ & $27.90 \pm 0.97$ & $05.73 \pm 4.31$ & $1.84 \pm 0.96$ \\
\hline
\end{tabular}



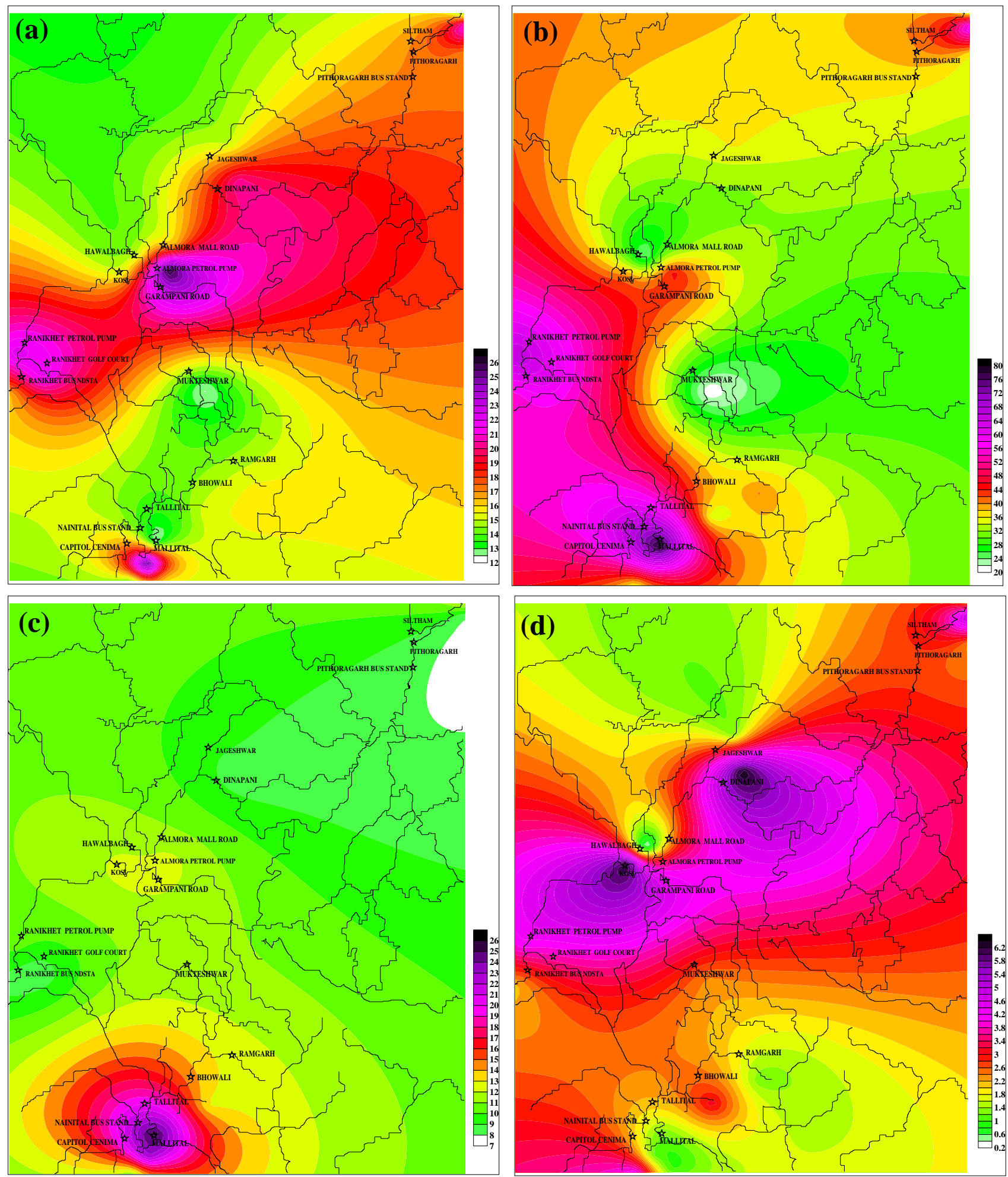

Fig. 3: Distribution map of metal content in Racomitrium crispulum rotherus ( $\mu \mathrm{gg}-1 \mathrm{dw}$ ) during winter 2004: (a) Pb, (b) $\mathrm{Zn}$, (c) $\mathrm{Cu}$ and (d) $\mathrm{Cd}$. 
Saxena et al. /Int. J. of Sustainable Water and Environmental Systems, Volume 6, No. 1 (2014) 1- 15
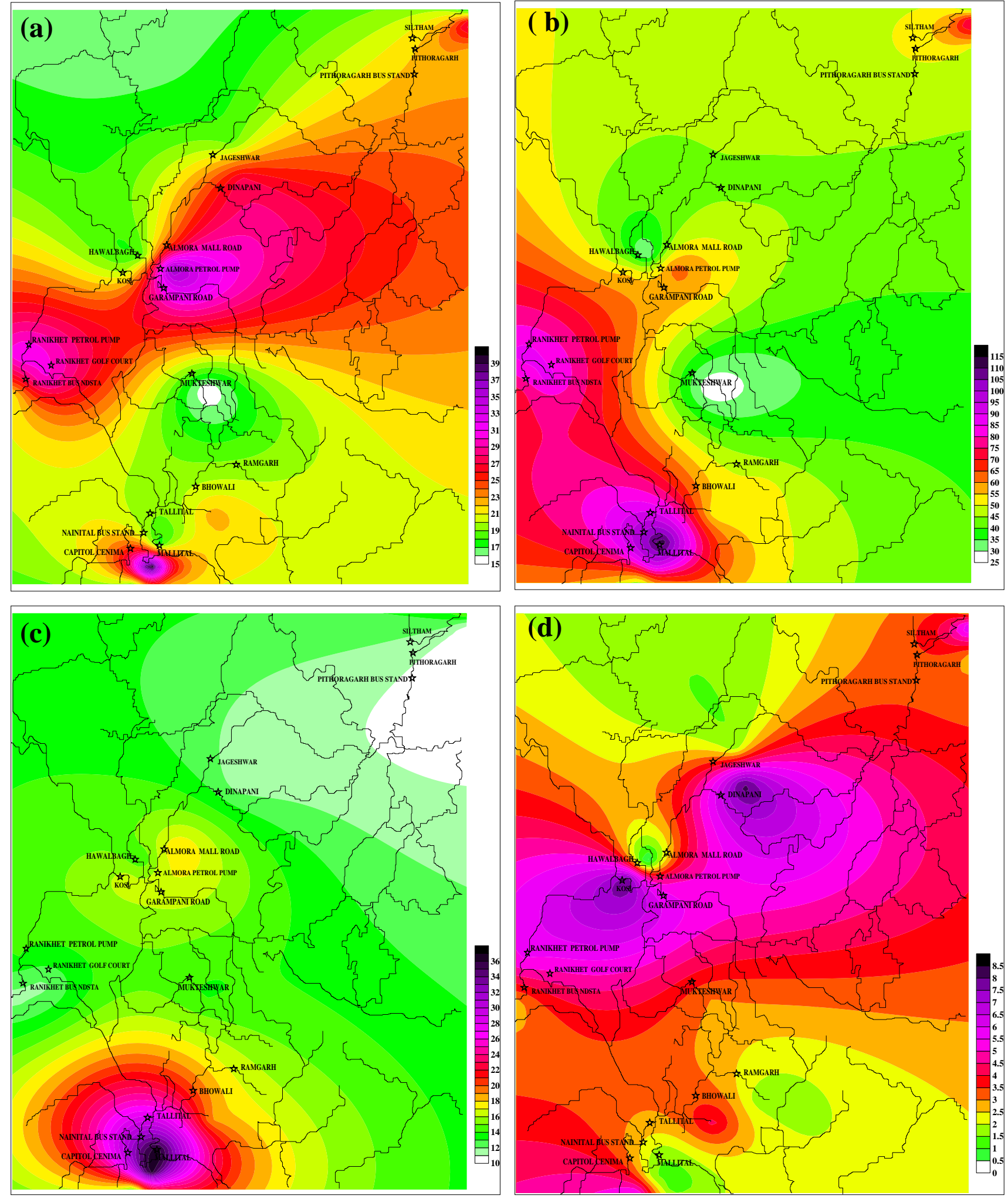

Fig. 4: Distribution map of metal content in Racomitrium crispulum ( $\mu \mathrm{g} g-1 \mathrm{dw}$ ) during summer 2004: (a) $\mathrm{Pb}$, (b) $\mathrm{Zn}$, (c) $\mathrm{Cu}$ and (d) $\mathrm{Cd}$. 

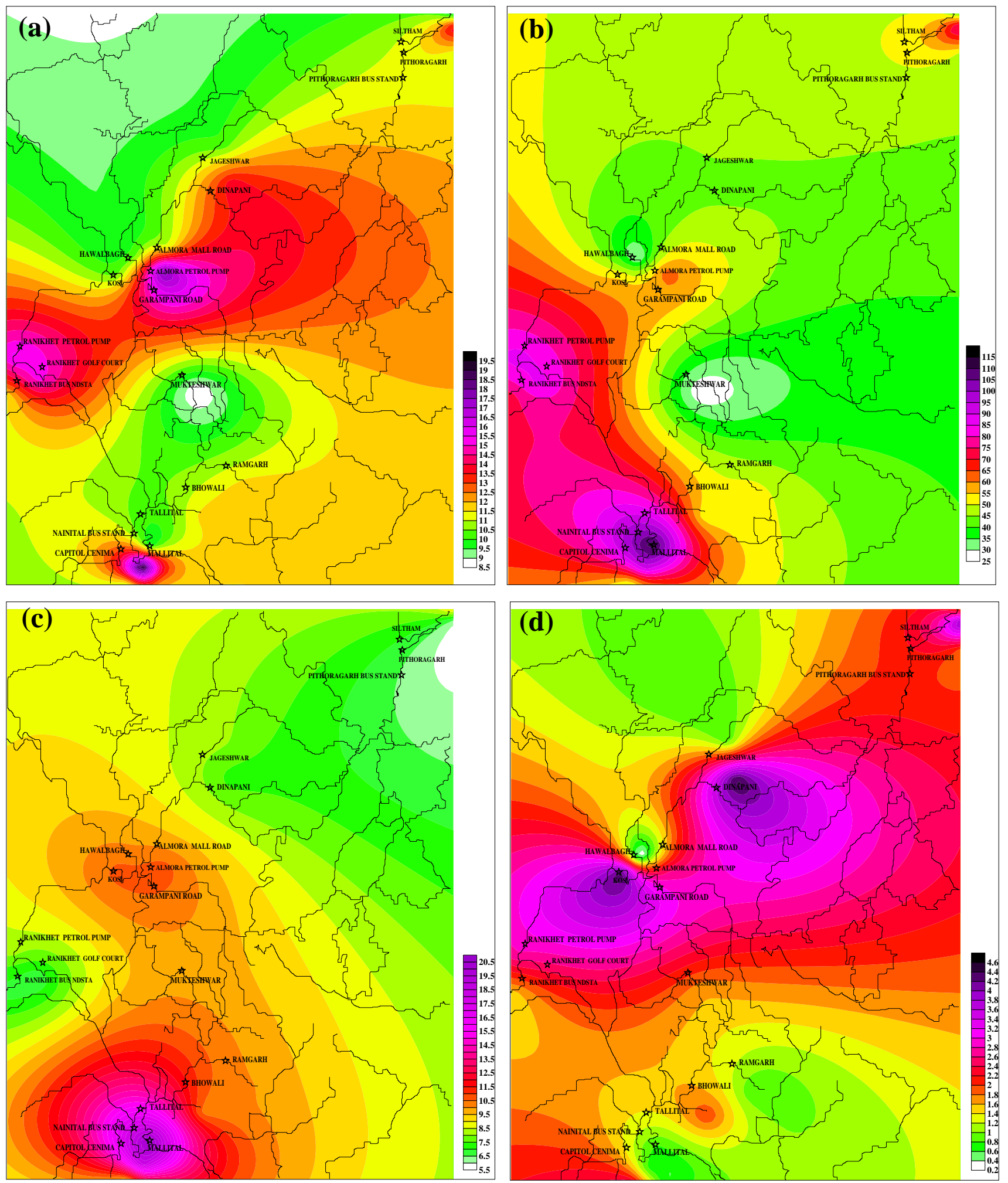

Fig. 5: Distribution map of metal content in Racomitrium crispulum ( $\mu \mathrm{g} \mathrm{g}-1 \mathrm{dw}$ ) during monsoon 2004: (a) $\mathrm{Pb}$, (b) $\mathrm{Zn}$, (c) $\mathrm{Cu}$ and (d) $\mathrm{Cd}$. 


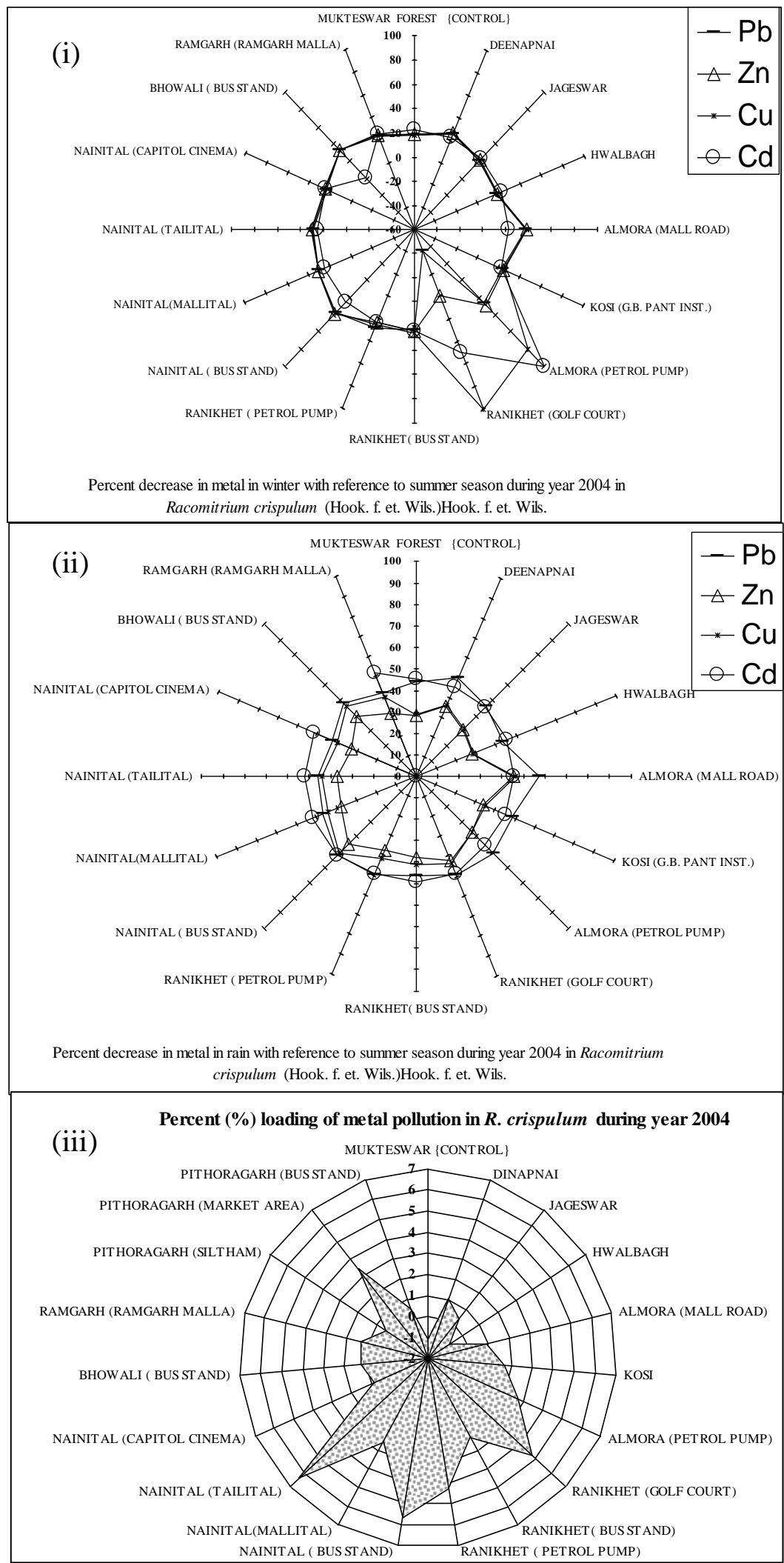

Fig. 6: Percent decrease in metal in (i) winter and (ii) monsoon with reference to summer season during year 2004 (iii) percent metal load (\%) by using moss Racomitrium crispulum as a biomonitoring species exposed in Kumaon hills. 